\title{
Challenges and Advances in SLE Autoantibody Detection and Interpretation
}

May Y. Choi, MD

Marvin J. Fritzler, PhD, $M D^{*}$

\section{Address}

${ }^{*}$ Cumming School of Medicine, University of Calgary, 3330 Hospital Dr. NW, Calgary, AB, T3H 1H7, Canada

Email: fritzler@ucalgary.ca

Published online: 7 May 2019

(C) The Author(s) 2019

This article is part of the Topical Collection on Lupus

Keywords SLE · Antinuclear antibodies (ANA) - Review • Autoantibodies

\begin{abstract}
Purpose of review This review is an overview of key autoantibodies used in the diagnosis and management of SLE. Questions addressed are the advantages to but limitations of ANA testing and what are the key considerations in ordering ANA tests and then interpreting the ANA results.

Recent findings There is a progressive move towards

- Solid-phase multi-analyte arrays with algorithmic analysis (SPMAAA)

- Closing the seronegative gap in SLE

- Harmonization of ANA testing

Summary As an approach to limiting morbidity and rising health care costs associated with SLE, the future of ANA testing should focus on making an accurate and actionable diagnosis of very early SLE. To achieve this goal, harmonization of autoantibody testing will be important.
\end{abstract}

\section{Introduction}

More than a half century has lapsed since the serendipitous discovery of the lupus erythematosus (LE) cell in systemic lupus erythematosus (SLE) and the development of the LE cell test by Hargraves and his colleagues at the Mayo Clinic [1]. While the description of cardiolipin and the biological false-positive Venereal Diseases
Research Laboratory (VDRL) test in SLE antedated the LE cell (reviewed in [2]), the LE cell discovery still serves as a historic reference point for the earliest studies of antinuclear antibodies (ANA). In the following 70 years, the spectrum of clinicians that use ANA for diagnosis and decision-making has markedly widened $[3,4]$. For 
example, ANA testing was once regarded the exclusive domain of rheumatologists and clinical immunologists, but today, it is also used by primary care providers and virtually all other subspecialists including nephrologists, dermatologists, respirologists, and neurologists [4]. The primary driver of this change is the remarkable spectrum of autoantibodies reported in systemic autoimmune rheumatic disease (SARD) and other autoinflammatory syndromes; in SLE alone, more than 180 autoantibodies have been described $[5,6]$. Some might regard the continuing search for new "esoteric" or rare autoantibodies in SLE [7] unnecessary but, for one thing, since approximately $5 \%$ of SLE patients are "seronegative" [8•], at a minimum, these efforts continue to narrow that "seronegative gap" [9].

There has also been a remarkable transition in the technologies used to detect autoantibodies that has been fostered by the "Golden Age" of cell and molecular biology that emerged in the mid-1970s [3, 10, 11•]. While some of the earlier immunoassays such as the LE cell test, double immunodiffusion, hemagglutination, complement fixation, radioimmunoassays, and counterimmunoelectrophoresis are rarely used today [10], the contemporary ANA indirect immunofluorescence assay (IFA) on HEp-2 cell substrates is increasingly used and has also become the screening test of choice for SLE [12]. One innovation that has sustained the use of
ANA IFA's is automated digitized microscopy that is capable of pattern recognition and, in some devices, digital algorithms to perform single-well titers [3, 13]. The American College of Rheumatology (ACR) and the European League Against Rheumatism (EULAR) are about to release new criteria (reviewed in $[14,15]$ ) based on a scoring system including a positive ANA at a titer $\geq 1: 80$ by IFA ("or its equivalent") occurring at least once as an entry criterion [16].

Newer solid-phase multi-analyte arrays (SPMAA) [17] have also emerged with higher throughput, sensitivity, and specificity while detecting a broader range of autoantibodies in comparatively miniscule serum samples [18]. A technological gap, however, is that SPMAA does not have on-board, real-time standards or calibrators for each antigen in an array, a gap that can be overcome [9]. Recent evidence also suggests that SPMAA is a more cost-effective approach than ANA IFA $[19,20]$. Universally accepted, standardized, and cost-effective follow-up ANA testing algorithms for SLE need to be developed. And with the advent of a new SLE classification criteria, better technologies, and novel autoantibodies, the purposes of this review are to summarize the advantages to and limitations of current ANA testing and to provide a general overview of important autoantibodies in SLE.

\section{Important considerations in interpretation of ANA test results and reports}

Before considering the clinical value of SLE-specific and SLE-associated autoantibodies, clinicians need to be aware of important limitations to ANA testing and interpretation of ANA test results (Table 1). Unfortunately, many multicenter studies and metanalysis seemingly fail to recognize the marked variability of ANA testing across different jurisdictions and how that impacts on the conclusions of their studies $[21,22]$. Autoantibodies are extremely complex because within any individual they can vary with time (although the precise chorological dynamics are poorly understood) and also vary between patients

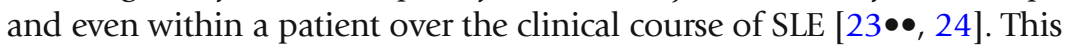
variability is likely related to the highly differing post-diagnostic clinical course of SLE that may be "relapsing-remitting," "chronically active," or "prolonged quiescence" [25]. In addition, the impact of therapeutic interventions and coincidental co-morbidities is very difficult to control for when results are obtained from cross-sectional samples. Hence, a critical factor in interpretation of ANA test is to appreciate that results obtained from cross-sectional SLE cohorts can be markedly different from inception cohorts because single-point 


\section{Table 1. Key considerations when interpreting ANA test results}

- Clinicians need to be aware which ANA screening test (ANA IFA or solid-phase multi-analyte autoantigen arrays (SPMAA)) their laboratory uses.

- Does their laboratory report all intracellular staining (i.e., cytoplasmic and mitotic patterns) or only nuclear staining on the ANA IFA test?

- What is the sensitivity, specificity, commutability, and reference range of their ANA assay?

- In interpreting published reports on ANA, was the test performed on an inception or cross-sectional SLE cohort?

- In SLE, autoantibodies to more than one autoantigen are typically found, and the combinations

of these various antibodies have important clinical associations.

- An important gap in ANA testing is the need for multicenter studies that use newer

SPMAA on cohorts of very early or incomplete SLE.

serological evaluations are unlikely to provide a realistic picture of the B cell response in SLE.

Another factor impacting on ANA test results and interpretation is that the ANA IFA test lacks accuracy and commutability (traceability, harmonization) of results $[23,26]$. Because achieving accuracy (closeness of a measured value to a standard or known value) of autoantibody assays is very challenging, assay precision (how close two or more assays are to each other or performance of an assay based on a predicate assay) is a common parameter used for reliable diagnostic assay design. Complete traceability [27, 28] and commutability [29] of ANA testing has yet to be achieved. As a caveat, although absolute standardization of autoantibody testing is generally recognized as extremely challenging, initiatives to improve standardization/harmonization within the wider field of in vitro diagnostics are underway [30].

One issue that contributes to the lack of harmonization and consensus in ANA IFA testing is whether cytoplasmic and mitotic patterns (CMP) should be considered as part of the ANA result. In an attempt to harmonize this definition of ANA, two separate international committees recommended that CMP should be included in the definition of ANA and that the nomenclature should be

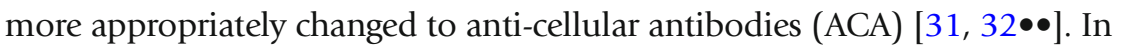
this manuscript, the term ANA (rather than ACA) is used simply because it is most widely recognized by clinicians. Nevertheless, it is important for the clinician to know if their diagnostic laboratory reports CMP staining in their ANA IFA results.

In addition, the harmonization of ANA IFA testing is challenging because other variables such as laboratory equipment (i.e., microscope optics and light sources), serum screening dilutions, and other factors have yet to be standardized $[33,34]$. There is evidence that the recent introduction of automated microscopic testing provides more harmonized ANA IFA results [35-37]. However, this technology requires a quality assurance program that addresses the total ANA IFA process. For example, the ANA IFA is semi-quantitative at best and although immunofluorescence intensity units can be obtained, this approach has yet to be approved by regulatory agencies [23]. Next, although, in general, higher titer antibodies have better clinical correlations [38, 39], autoantibodies directed to different intracellular targets and differing IFA patterns have differing dilution curves, so that some ANA IFA systems (i.e., anti-U1RNP, 
anti-Sm) may be regarded as high dilution/titer systems, whereas others (i.e., anti-SSA/Ro60, SS-B/La) are low dilution/titer systems [39]. Last, it should be appreciated that the ANA IFA test is only useful as a screening test and specific antibodies should be confirmed through the identification of specific antibodies using SPMAA [40].

Perhaps the significant challenges to harmonization, commutability, and traceability of the ANA IFA test are inconsequential because modern diagnostic laboratories are progressively migrating to SPMAA diagnostic platforms that have higher throughput and faster turn-around-times but, more importantly, utilize definable analytes/autoantigens in their test platforms [19, 41]. For the most part, SPMAAs are widely available and are currently used either as an approach to the diagnosis of specific SARDs (i.e., separate SLE, scleroderma (SSc), Sjögren's syndrome (SjS), autoimmune inflammatory myopathy (AIM) profiles), and/or the most common targets seen in SARDs included in a SARD screen as an alternative to the ANA IFA. However, there is some evidence that while SPMAA are a significant move forward, combining ANA IFA with SPMAA has higher clinical impact than either of the tests alone [3, 20, 36, 42, 43]. SLE serum samples that have negative SPMAA test results should ideally be tested by ANA IFA to determine if antibodies to targets not included in the SPMAA are detected.

Last, it is well known that SLE patients commonly have more than one autoantibody, typically reflecting what has been called "linked sets" [44] or B cell responses to macromolecular complexes such as spliceosomes, nucleosomes, and/or cytoplasmic ribonucleoprotein complexes. With the advent of SPMAA, it has been increasingly appreciated that combinations and permutations of autoantibodies in SLE can be associated with unique phenotypes. For example, a combination of anti-dsDNA and antinucleosome antibodies is reported to differentiate lupus nephritis (LN) from SLE without LN; antidsDNA plus anti-histone and antinucleosome antibodies are associated with a higher risk of severe LN than what can be attributed to the individual autoantibodies alone [45]. When anti-Ro52/TRIM21, anti-Ro60/SS-A, and anti-SS-B/ La were found together, they were associated with xerostomia and xerophthalmia $(p<0.001)$ [46]. Oral ulceration was associated with anti-Ro52/TRM21 and anti-Ro60/SS-A positivity but anti-SS-B/La negative ( $p$ 0.002) and alopecia was associated with anti-Ro60/SS-A positivity but anti-Ro52/TRIM21 and anti-SS-B/ La negativity ( $p$ 0.003) [46]. Further, when anti-Ro52/TRIM21 antibodies were found in isolation, there was a negative association with xerophthalmia and photosensitivity with anti-Ro60/anti-La ( $p$ 0.003). These observations and others like them illustrate the limitations of interpreting the frequencies and clinical associations of any individual ANA result.

\section{Specific autoantibodies}

Since over 180 autoantibodies have been reported in SLE, a general context and consensus of only the key autoantibodies is discussed here. The frequency of the various autoantibodies is shown in Table 2 . In the following discussion, when ANA IFA patterns on HEp-2 cells are referred to, they are cross-referenced to the corresponding AC-' $\mathrm{X}$ ' nomenclature proposed by the International Consensus on Autoantibody Patterns (ICAP: https://anapatterns.org/index.php). 
Table 2. Prevalence and clinical associations of SLE autoantibodies

\begin{tabular}{|c|c|c|c|c|}
\hline $\begin{array}{l}\text { Antibody } \\
\text { target }\end{array}$ & $\begin{array}{l}\text { Prevalence } \\
\text { range* } \\
(\%)\end{array}$ & $\begin{array}{l}\text { Prevalence in } \\
\text { inception } \\
\text { SLICC cohort } \\
(n=1049) * * \\
(\%)\end{array}$ & Clinical associations & Comments \\
\hline dsDNA & $30-70$ & 40.5 & $C C, \mathrm{LN}$ & $\begin{array}{l}\text { Pathogenic: test results can } \\
\text { vary depending on } \\
\text { immunoassay used }\end{array}$ \\
\hline $\begin{array}{l}\text { Nucleosomes } \\
\text { chromatin }\end{array}$ & $20-70$ & N/A & $\begin{array}{l}\text { LN, more severe disease } \\
\text { progressive renal failure; } \\
\text { disease activity; DIL }\end{array}$ & $\begin{array}{l}\text { Pathogenetic: Note-many } \\
\text { drugs originally associated } \\
\text { with anti-histone and DIL } \\
\text { are no longer in wide use; } \\
\text { harder to obtain validated } \\
\text { assays because of } \\
\text { difficulty standardizing } \\
\text { the target macromolecular } \\
\text { nucleocomplex }\end{array}$ \\
\hline Histone & $10-80$ & 40.1 & SLE, drug-induced SLE; NPSLE & $\begin{array}{l}\text { Frequency depends on assay } \\
\text { and which histones are } \\
\text { included; higher titers, } \\
\text { especially anti-H2B, } \\
\text { anti-H4, acetylated H4, } \\
\text { and H2A more specific for } \\
\text { SLE }\end{array}$ \\
\hline $\begin{array}{l}\text { High-mobility } \\
\text { group } \\
\text { proteins }\end{array}$ & $20-49$ & N/A & SLE disease activity & $\begin{array}{l}\text { Sensitivity and specificity } \\
\text { varies depending on the } \\
\text { HMG protein being } \\
\text { studied. }\end{array}$ \\
\hline $\begin{array}{l}\text { Dense fine } \\
\text { speckled } 70\end{array}$ & $1-10$ & 7.1 & $\begin{array}{l}\text { Monospecific antibodies rare in } \\
\text { SLE }\end{array}$ & $\begin{array}{l}\text { Reported in variety of } \\
\text { autoinflammatory } \\
\text { syndromes and health } \\
\text { individuals. Monospecific } \\
\text { antibodies may be used to } \\
\text { ruling out diagnosis of SLE } \\
\text { and other SARD. }\end{array}$ \\
\hline $\begin{array}{l}\text { Sm (U2-U6 } \\
\text { RNP) }\end{array}$ & $5-30$ & 24.7 & $\begin{array}{l}\text { CC, serositis, LN, NPSLE, CSF, } \\
\text { NPSLE }\end{array}$ & $\begin{array}{l}\text { Predictive: SmD3 containing } \\
\text { a symmetrical } \\
\text { dimethylarginine at } \\
\text { position } 112 \text { most specific } \\
\text { for SLE }\end{array}$ \\
\hline U1-RNP & $15-50$ & 32.4 & $\begin{array}{l}\text { Leukopenia; NPSLE; ILD: IgM } \\
\text { anti-U1RNP antibodies } \\
\text { predominant in SLE compared to } \\
\text { IgG anti-U1RNP without IgM } \\
\text { more frequent in MCTD }\end{array}$ & $\begin{array}{l}\text { Anti-U1RNP in CSF } 64.3 \% \\
\text { sensitivity and } 92.9 \% \\
\text { specificity for NPSLE }\end{array}$ \\
\hline Ribosomal P & $10-30$ & 16.1 & $\begin{array}{l}\text { Renal disease; malar rash; possibly } \\
\text { NPSLE; antibodies to C22 } \\
\text { peptide highly specific for SLE }\end{array}$ & $\begin{array}{l}\text { Associated with anti-dsDNA; } \\
\text { although C22 of protein } \\
\text { has the most specific SLE }\end{array}$ \\
\hline
\end{tabular}


Table 2. (Continued)

\begin{tabular}{|c|c|c|c|c|}
\hline $\begin{array}{l}\text { Antibody } \\
\text { target }\end{array}$ & $\begin{array}{l}\text { Prevalence } \\
\text { range* } \\
(\%)\end{array}$ & $\begin{array}{l}\text { Prevalence in } \\
\text { inception } \\
\text { SLICC cohort } \\
(n=1049) * * \\
(\%)\end{array}$ & Clinical associations & Comments \\
\hline & & & & $\begin{array}{l}\text { epitope, not all assays } \\
\text { utilize this peptide in their } \\
\text { assays; prevalence varies } \\
\text { in different countries }\end{array}$ \\
\hline SS-A/Ro60 & $25-60$ & 47.3 & $\begin{array}{l}\text { SCLE, C } 4 \text { deficiency, NLE; in } \\
\text { pediatric SLE milder disease } \\
\text { (cutaneous, MSK) }\end{array}$ & $\begin{array}{l}\text { Predictive: titers important } \\
\text { in NLE }\end{array}$ \\
\hline Ro52/TRIM21 & $10-40$ & 35.9 & $\begin{array}{l}\text { Leukopenia; } 70 \% \text { of patients with } \\
\text { anti-Ro52 but not anti-Ro60- } \\
\text { antibodies have SARD (majority } \\
\text { have UCTD followed by SLE); } \\
\text { ANA negative SLE }\end{array}$ & $\begin{array}{l}\text { Seen in patients with } \\
\text { malignancy with or } \\
\text { without evidence of SARD }\end{array}$ \\
\hline SS-B/La & $5-25$ & 15.9 & $\begin{array}{l}\text { SjS, SCLE; NLE, leukopenia, } \\
\text { serositis; rare in pediatric SLE }\end{array}$ & Protective: less renal disease \\
\hline $\mathrm{C} 1 \mathrm{q}$ & $15-60$ & $\mathrm{~N} / \mathrm{A}$ & $\begin{array}{l}\text { Lupus nephritis; prevalence } 13 \% \text { in } \\
\text { controls }\end{array}$ & $\begin{array}{l}\text { Simultaneously positive } \\
\text { anti-C1q, anti-dsDNA and } \\
\text { low complement was } \\
\text { strongly associated with } \\
\text { renal involvement }\end{array}$ \\
\hline $\mathrm{Ku}$ & $5-20$ & $\mathrm{~N} / \mathrm{A}$ & $\begin{array}{l}\text { Not specific for SLE; SSc and } \\
\text { myositis overlap; other SARD; } \\
\text { Raynaud's, myositis, arthritis; } \\
\text { UCTD }\end{array}$ & $\begin{array}{l}\text { Ku is a heterodimer } \\
\text { consisting of } 70 \mathrm{kDa}(\mathrm{p} 70) \\
\text { and } \sim 80 \mathrm{kDa}(\mathrm{p} 80) \text { protein } \\
\text { subunits that binds } \\
\text { blunt-ends of } x \text {-ray } \\
\text { damaged DNA. }\end{array}$ \\
\hline PCNA & $0.5-5$ & 7.3 & $\begin{array}{l}\text { More severe SLE; may be } \\
\text { transiently expressed and/or } \\
\text { decreased with therapy }\end{array}$ & $\begin{array}{l}\text { PCNA is the auxiliary protein } \\
\text { of DNA polymerase delta } \\
\text { component of a } \\
\text { macromolecular complex } \\
\text { when IFA and SPMAA, } \\
\text { specific for SLE. }\end{array}$ \\
\hline Cardiolipin & $20-60$ & 12.6 & $\begin{array}{l}\text { CC, APS; thrombosis; pulmonary } \\
\text { hypertension }\end{array}$ & $\begin{array}{l}\text { Predictive: decreased } \\
\text { survival }\end{array}$ \\
\hline AMA M5 & $\sim 25$ & $\mathrm{~N} / \mathrm{A}$ & APS & $\begin{array}{l}\text { Closes serological gap in APS; } \\
\text { thrombocytopenia, fetal } \\
\text { loss, lupus anticoagulant; } \\
\text { associated with } \\
\text { anticardiolipin, } \\
\text { anti- } \beta 2 G \mathrm{GP} \text {, and } \\
\text { biologically false-positive } \\
\text { VDRL }\end{array}$ \\
\hline$\beta 2 \mathrm{GP} 1$ & $30-45$ & 14.0 & CC, APS & $\begin{array}{l}\text { Predictive of thrombosis and } \\
\text { fetal loss: closes }\end{array}$ \\
\hline
\end{tabular}


Table 2. (Continued)

\begin{tabular}{|c|c|c|c|c|}
\hline \multirow[t]{2}{*}{$\begin{array}{l}\text { Antibody } \\
\text { target }\end{array}$} & $\begin{array}{l}\text { Prevalence } \\
\text { range* } \\
(\%)\end{array}$ & $\begin{array}{l}\text { Prevalence in } \\
\text { inception } \\
\text { SLICC cohort } \\
(n=1049) * * \\
(\%)\end{array}$ & Clinical associations & Comments \\
\hline & & & & $\begin{array}{l}\text { serological gap in APS; } \\
\text { glycosylation of Fc domain } \\
\text { of anti- } \beta 2 \mathrm{GP} 1 \text { may be } \\
\text { important in pathogenesis }\end{array}$ \\
\hline $\begin{array}{l}\text { B2GP1 domain } \\
1\end{array}$ & $40-56$ & N/A & APS & $\begin{array}{l}\text { Higher specificity than full } \\
\text { length } \beta 2 \mathrm{GP} 1 ; \mathrm{IgA} \\
\text { antibodies important }\end{array}$ \\
\hline PS/PT & $30-54$ & $\mathrm{~N} / \mathrm{A}$ & $\begin{array}{l}\text { APS; correlated with lupus } \\
\text { anticoagulant and increased risk } \\
\text { of thrombosis }\end{array}$ & $\begin{array}{l}\text { May be a surrogate biomarker } \\
\text { for lupus anticoagulant. } \\
\text { Commercial kit available. }\end{array}$ \\
\hline $\begin{array}{l}\text { AMA M5 anti-mitc } \\
\text { confidence interva } \\
\text { disease, } k D a \text { kilod } \\
\text { not assessed, NLE } \\
\text { phosphatidyl seri } \\
\text { lupus erythemato } \\
\text { undifferentiated } \\
{ }^{*} \text { For interpretatio }\end{array}$ & $\begin{array}{l}\text { ondrial M5 type } \\
\text { SF cerebrospinal } \\
\text { n, } L N \text { lupus nep } \\
\text { onatal lupus en } \\
\text { prothrombin cor } \\
\text { SjS Sjögren's sy } \\
\text { nective tissue di } \\
\text { see Table } 1 \text { and }\end{array}$ & $\begin{array}{l}\text { ibodies, } A P S \text { antiph } \\
\text { id, DIL drug-induced } \\
\text { S, SPMAA multi-analy } \\
\text { matosus, NPSLE net } \\
\text { ex, RNP ribonucleop } \\
\text { me, SS- } A \text {, SS-B Sjög } \\
\text { se, VDRL Venereal Di } \\
\text { ion "Important cons }\end{array}$ & $\begin{array}{l}\text { holipid syndrome, } \beta 2 G P 1 \text { beta } 2 \text { glycopro } \\
\text { us, dsDNA double-stranded DNA, HMG high } \\
\text { antigen array, MCTD mixed connective tiss } \\
\text { sychiatric SLE, OR odds ratio, PCNA proli } \\
\text { in, SARD systemic autoimmune rheumati } \\
\text { syndrome antigens A and B, SSC systemic } \\
\text { e Research Laboratory } \\
\text { ations in interpretation of ANA test resul }\end{array}$ & $\begin{array}{l}\text { in } 1, C C \text { classification criteria, CI } \\
\text { obility group, ILD interstitial lung } \\
\text { disease, MSK musculoskeletal, N/A } \\
\text { ating cell nuclear antigen, PS/PT } \\
\text { lisease, SCLE subacute cutaneous } \\
\text { erosis, TRIM tripartite motif, UCTD } \\
\text { and reports." ** Reference [8•] }\end{array}$ \\
\hline
\end{tabular}

Autoantibodies directed against chromatin components are typically associated with a homogenous (AC-1) or dense fine speckled (DFS) pattern (AC-2) on HEp-2 IFA. Exceptions are antibodies directed specifically to histone (H1), the inner core histones (H3, H4), and high-mobility group (HMG) proteins, which have no known consistent IFA pattern.

\section{Double-stranded DNA}

Antibodies directed to double-stranded DNA (dsDNA) were one of the first, disease-specific B cell targets described in SLE (reviewed in [47••, 48]). AntidsDNA antibodies are typically associated with LN [49] and can be used to monitor disease activity $[47,50]$. It is important to appreciate that the antidsDNA system is highly complex and this, in part, is reflected by the performance of different immunoassays and diagnostic platforms used to detect them. Historically, the Farr radioimmunoassay was preferred because it reputedly measured primarily high affinity antibodies and hence reflected a more "trained" B cell response in addition to antibodies that likely had pathogenic potential in LN. The Farr assay has become decreasingly used because of safety concerns with assays that employ radioisotopes and there was a tendency of the kits to be in short supply. Hence, many laboratories reverted to other assays such as addressable laser bead immunoassay (ALBIA), enzyme-linked immunosorbent assay (ELISA), chemiluminescence immunoassay (CIA), and the Crithidia luciliae IFA 
[47]. One ongoing issue is whether a negative ANA IFA result is a "false negative" when the results of any of the SPMAA anti-dsDNA tests listed above are positive. To address this apparent paradox, it is important to recognize the highly complex nature of dsDNA and appreciate that in cells (i.e., HEp-2) where dsDNA is bound by histones, HMG proteins, and other DNA-binding proteins and stabilized with organic fixatives, there is no a priori reason to expect complete agreement of results ANA IFA and SPMAAs when the latter use purified or synthetic dsDNA. For a more thorough discussion of limitations of anti-dsDNA testing, the reader is referred to a recent review $[47 \bullet \bullet]$.

\section{Histones}

Histones are a class of low molecular weight, cationic proteins that are bound to nuclear dsDNA. Histones can be subclassified as cross-linkers of DNA and the nucleosome (H1) or components of the core nucleosome body (H2a, H2b, H3, and H4) [51]. Methylated, acetylated and other posttranscriptional modified histones are now known to be critical in the epigenetic gene expression [52]. In addition, they are components of apoptotic bodies [52,53] and neutrophil extracellular traps (NETS) [54], which are considered to be important pathogenic phenomena in SLE [55]. As compared to antibodies to the core histones, antibodies directed to $\mathrm{H} 1$ and its variants are the least specific for SLE. Although antibodies to histones and nucleosome have been primarily linked to drug-induced lupus (DIL) $[55,56]$, it is important to appreciate that this association was more relevant to drugs that are no longer in wide use (e.g., hydralazine, procainamide) compared to the biological therapeutic-induced DIL that is more prevalent today. Since histones are key components of the nucleosome, antibodies to the nucleosome are considered more diagnostically relevant.

\section{Nucleosomes}

The terms antinucleosome and anti-chromatin antibodies tend to be used interchangeably; however, an important distinction is that although the term "chromatin" encompasses nucleosomes, nucleosomes are more restricted in their molecular structure(s) and components, the latter largely relegated to dsDNA complexed to histones as described above, while chromatin contains dsDNA, HMG proteins, and other gene-regulatory elements [51]. Hence, most commercially available assays are based on purified nucleosomes that have been further processed to remove the inter-nucleosome linker DNA as well as less avidly bound proteins such as HMGs and H1. In this format, antinucleosome antibodies are highly, but not exclusively, correlated with anti-dsDNA and are highly specific for SLE [51, 57]. In some studies, nucleosomes and antinucleosome antibodies are thought to be more pathogenic than anti-dsDNA. Antinucleosome antibodies have been reported to antedate the appearance of antidsDNA and predict the development of SLE in patients who developed renal failure [58] and antiphospholipid syndrome (APS) [59]. Despite numerous publications indicating the importance of antinucleosome antibodies as biomarkers for SLE [51, 60, 61], other less favorable views have been offered [62•]. 


\section{High-mobility group proteins}

HMG proteins are a family of low molecular weight, chromatin-associated proteins that, except for HMG box protein-1 (HMGB1) and HMG box protein-2 (HMGB2), primarily bind to linker (i.e., non-nucleosome) DNA. Although HMGB1 is typically associated with nucleosomes, it also shuttles between the nucleus and the cytoplasm. HMGB1 consists of three separate domains: Box A, Box B, and an acidic tail of which Box A acts as a competitive antagonist for HMGB1 and has been considered as a potential treatment option for SLE [63]. Much interest has focused on HMGB1 because it is secreted by inflammatory cells and passively released from apoptotic and necrotic cells, where it has proinflammatory effects $[64,65]$. It has been suggested that HMGB1 helps elicit anti-dsDNA antibody production in SLE [66]. The titers of anti-HMGB1 antibodies correlated with anti-dsDNA antibody levels $(r=0.49 ; p<0.001)$ and less pronounced correlations were observed with SLE disease activity index

(SLEDAI-2K) $(r=0.15 ; p=0.04)$, low C4 $(r=-0.23 ; p=0.002)$, low C3 levels, and proteinuria $[63,67]$. These observations suggested that HMGB1-anti-HMGB1 immune complexes play a role in the pathogenesis of LN. Titers of anti-Box A antibodies were also increased in 73\% of patients with LN and 71\% of non-LN flares. It was concluded that antibodies to the HMGB1 Box A domain of might be a novel biomarker for SLE.

Anti-HMGB1/HMGB2 antibodies were detected in SLE, rheumatoid arthritis (RA), SjS, and SSc [66]. Of interest, HMGBI and HMGB2 may be target antigens of perinuclear neutrophil cytoplasmic antibodies (pANCA). However, antiHMGB1 antibodies were not associated with ANCA-associated vasculopathies [68]. Autoantibodies to another HMG protein, such as the structure specific recognition protein I (SSRP1) was identified by ELISA and western blot in $28 \%$ of SLE sera, compared to $8.3 \%$ of healthy individuals but not in other SARD [69].

\section{Dense fine speckled}

The typical DFS IFA staining pattern is recognized as uniformly distributed fine speckles throughout interphase nuclei and on metaphase chromatin (AC-2) (reviewed in $[70 \bullet \bullet, 71])$. The target antigen associated with the DFS IFA pattern was first identified as dense fine speckled 70 (DFS70) based on the apparent molecular weight of $70 \mathrm{kDa}$, but the protein was later recognized as the lens epithelium-derived growth factor (LEDGF) and more recently as the DNAbinding transcription coactivator p75 [72]. Since the first report in interstitial cystitis, anti-DFS70 antibodies have been reported in patients with a variety of chronic inflammatory conditions, cancer, and most notably in healthy individuals $[70 \bullet \bullet, 71,73]$. Anti-DFS70 antibodies are now recognized as one of the key targets in high titer positive ANA IFA healthy and non-SARD sera [74]. Isolated (monospecific or no other detectable autoantibodies) anti-DFS70 antibodies described in healthy individuals were rarely found in SLE but were found associated with SLE-related autoantibodies in a small proportion of sera [75]. Hence, the presence of anti-DFS70 in SLE sera is currently thought to have limited clinical value. A recent report indicates geographic differences in the prevalence of anti-DFS70 antibodies and that they occur preferentially in females and young individuals [76]. 


\section{Small nuclear ribonucleoproteins: Sm and U1-RNP}

Autoantibodies directed against small nuclear ribonucleoproteins (snRNP) components (Sm, U1-RNP) are typically associated with nuclear speckled (AC-4; AC-5) patterns on HEp-2 IFA. Anti-Sm antibodies are highly specific for SLE. By comparison, although anti-Sm and anti-U1RNP commonly coexist in SLE, anti-U1RNP antibodies are found in patients with a variety of other SARD (reviewed in [77]). Although anti-Sm is one of the most widely requested autoantibody tests, it lacks sensitivity because it is present in only 5-30\% of SLE patients [78]. Nevertheless, largely because of its high specificity, it is one of the serologic criteria in the ACR [79] and SLICC [80] Classification Criteria for SLE. Although anti-Sm is associated with classical SLE, it is also seen in patients with SLE-overlap syndromes [77]. AntiSm antibodies have been described in patients without SLE, although follow-up studies showed that some eventually developed that disease [77]. These observations highlight the importance of Sm and other SLE-specific autoantibodies as predictors of SLE [81]. The titers of anti-Sm antibodies have been reported to correlate with disease activity, milder renal and central nervous involvement, or late-onset LN, but these associations are controversial [7]. Twenty-five to forty percent of anti-U1RNP-positive SLE patients also have anti-Sm, although this varied in different cohorts [78]. Even though anti-U1RNP antibodies are found in a high proportion of SLE, they are also reported in SSc, AIM, SjS, and other SARD. By comparison, all ( $100 \%)$ patients with mixed connective tissue disease (MCTD) are, by definition, positive for anti-U1RNP antibodies. However, anti-U1RNP antibodies are not a specific biomarker for MCTD. Regardless of the disease association, anti-U1RNP-positive patients typically have Raynaud's phenomenon, swollen digits, and leukopenia [82].

\section{DNA-dependent protein kinase (DNA-PK/Ku)}

$\mathrm{Ku}$ is a heterodimer composed of 70 and $\sim 85 \mathrm{kDa}$ non-histone nuclear proteins. This antigen has gained research interest because it is a DNA-dependent protein kinase (DNA-PK) that is critical in the repair of double-strand DNA breaks induced by ionizing radiation [83]. Antibodies to various components of this macromolecular DNA-PK complex have been reported in SLE and related SARD [84]. Although initially thought to be specific for polymyositis/SSc overlap syndrome [85], subsequent studies demonstrated that anti-Ku antibodies are also found in SLE, MCTD and SSc [86-88]. Additional studies revealed that anti-Ku antibodies were also detected in a variety of other SARD and were associated with polymyositis/SSc overlap syndrome in Japanese cohorts but with SLE and overlap syndromes in African-American cohorts [87]. In a small Japanese polymyositis/SSc overlap syndrome cohort $(n=11)$, precipitating autoantibodies to Ku were found in $55 \%$ as compared to $6 \%$ of Japanese SLE patients and $<1 \%$ of other SARD [85]. In African-American individuals, these antibodies were most strongly associated with SLE (14\%), whereas in Caucasian people, anti-Ku antibodies are rare regardless of the clinical diagnosis [87]. Overall, anti-Ku autoantibodies are relatively rare, being reported in $4 \%$ of patients with MCTD/overlap syndrome and in $<1 \%$ of SLE, and even rarer in other SARD. More multicenter studies of inception cohorts of SLE and other SARDS using newer diagnostic platforms that include Ku as an analyte are needed. 


\section{Sjögren syndrome antigen B/La}

Autoantibodies directed against Sjögren syndrome antigen B (SS-B)/La are highly specific ( $\sim 90 \%$ ) and sensitive ( $\sim 85 \%)$ for SjS [89, 90]. The prevalence of these antibodies is also high in mothers that give birth to infants with neonatal lupus syndrome (NLS) [91]. In NLS, approximately $10-15 \%$ of cases of congenital heart block are not exposed to anti-Ro60/SS-A or SS-B/La [91] while the cutaneous manifestations of NLS were reported in infants exposed only to antiU1RNP antibodies [91]. It was reported that anti-SS-B/La and Ro60/SS-A antibodies can be detected 2.8 years before the onset of the symptoms and 3.6 years before diagnosis of SLE [92], suggesting a predictive role. SLE patients that have anti-SS-B/La antibodies usually develop secondary SjS syndrome. Anti-SS-B/La autoantibodies are rarely found alone, usually coinciding with anti-Ro60/SS-A autoantibodies [90].

\section{Ribosomal P}

Autoantibodies to ribosomes were first described in the 1960s in SLE sera followed by identification of key ribosomal proteins (Rib-P) in the 1970s [93, 94] and three of the ribosomal phosphoproteins (P0, P1, P2) in the 1980s [95, 96]. The Rib-P are largely localized to the cytoplasm and are components of the $60 \mathrm{~S}$ ribosomal subunit [93]. Over the years, anti-Rib-P antibodies have been the subject of extensive study and have been shown to be a highly specific biomarker for the diagnosis of SLE [97-99]. They are associated with LN, autoimmune hepatitis and, although controversial, with neuropsychiatric SLE (NPSLE) subset [100, 101]. Experimental evidence indicates that anti-Rib-P have a pathogenic role in LN and NPSLE. Despite remarkable evidence for their high disease specificity, anti-Rib-P have not been included in classification or diagnostic criteria for SLE. A significant challenge in interpreting the published literature is the variability of diagnostic platforms used to detect anti-Rib-P and the antigens included in the assays. Evidence indicates that the major epitope is localized to the C-terminal 22 amino acids [98, 102], and some diagnostic assays use this analyte in their assays but other assays use various combinations of the other Rib$\mathrm{P}^{\prime} \mathrm{s}[103,104]$. This likely accounts for the marked discrepancies in frequencies $(10-47 \%)$ and association with clinical and demographic features reported in SLE cohorts. Although Rib-P proteins are localized in the cytoplasm, ANA IFA is not a reliable screening method to detect them [104, 105], but when it is positive, it is typically associated with a cytoplasmic AC-19 pattern. Anti-Rib-P antibodies commonly coexist with anti-dsDNA and anticardiolipin (aCL) antibodies [106, 107] and this may account with the observed association with LN and NPSLE.

\section{Ro60/SSA}

In general, anti-Ro60/SS-A antibodies are not reliably detected by most ANA IFA screening assays. An exception is a specialized HEp-2 substrate (HEp-2000, Immuno Concepts) that has been transfected with the Ro60/SS-A gene where it is overexpressed in some cells and more reliably detected by IFA [108]. Depending 
upon the method of detection and the cohort being studied, anti-Ro60/SS-A is found in up to $50 \%$ of patients with SLE. By comparison, the prevalence of antiRo60/SS-A is up to $85 \%$ in SjS. The prevalence of anti-Ro60/SS-A is similarly high in mothers of infants with NLS and subacute cutaneous lupus. A much lower prevalence $(<25 \%)$ of anti-Ro60/SS-A is seen in SSc, AIM, RA, and autoimmune liver diseases. In SLE, anti-Ro60/SS-A is associated with photosensitive skin rash, elevated serum immunoglobulins, lower complement levels, lymphopenia, and leukopenia. In SLE the combination of anti-Ro60/SS-A and anti-SS-B/La may be protective against neurologic and kidney disease among patients [109]. Antibodies to anti-Ro60/SS-A have been reported to be one of the earliest antibodies to appear years before a diagnosis of SLE is made [92].

\section{R052/TRIM21}

Ro52/TRIM21 is a 52-kDa member of the tripartite motif-containing (TRIM) super family of proteins, is a factor in innate and acquired immunity and pathological autoimmune processes, and is an interferon-(IFN-) inducible protein in some cells [110]. Its role in pathological autoimmune processes includes the aberrant ubiquitylation of the interferon-regulatory factor (IRF) family of proteins, regulation of type I interferon and pro-inflammatory cytokines $[110,111]$, is a key effector in the toll-like receptor 3 pathway [112], and is linked to IL-23 and BAFF expression [111]. Hence, Ro52/TRIM21 has been purported as an attractive therapeutic target for SLE [110]. Anti-Ro52/TRIM21 antibodies are not detected by conventional HEp-2 ANA IFA.

Ro52/TRIM21 was initially reported to be part of the same antigenic macromolecule as Ro60/SS-A and the B cell response to these two targets were strongly linked (reviewed in [113]) Subsequently, both of these claims were shown to be incorrect, but the medical literature is confounded because many commercially available diagnostics assays included both Ro52/TRIM21 and Ro60/SS-A in a single test and many reports of clinical associations linked both targets together. As a result, detailed studies using anti-Ro52/TRM21 as a separate analyte are now needed. When this has been done, anti-Ro52/TIRM21 was found to be not specific for any SARD [114], but in SSc and MCTD, were reported to be associated with polyautoimmunity (i.e., patients that have more than one autoimmune condition), interstitial lung disease, rheumatoid factor [114, 115], and in SjS with more aggressive disease [116]. In SLE using line immunoassay (LIA) and ELISA, monospecific anti-Ro52/TRIM21 was observed in 6/67 (5.9\%) and was most commonly associated with anti-Ro60/SS-A (22/ $67,32.8 \%)$ [114]. In other studies, this autoantibody was associated with leukopenia and $~ 70 \%$ of patients with anti-Ro52/TRIM21 but no anti-Ro60/SSA antibodies had undifferentiated connective tissue disease (UCTD) or SLE [46, $117,118]$.

\section{Cell cycle}

\section{Proliferating cell nuclear antigen}

Antibodies directed to the $35-\mathrm{kDa}$ proliferating cell nuclear antigen (PCNA) were first described in a Japanese female with SLE (reviewed in [119]). The identification of anti-PCNA and its purported high specificity 
for SLE was based on a unique cell cycle IFA pattern on HEp-2 cells (AC13 ) and a specific immunoprecipitation line in double immunodiffusion. However, subsequent studies that used other assays such as LIA, ELISA, and ALBIA [119] indicated that anti-PCNA antibodies were not specific for SLE [120]. Further studies (unpublished) indicate that the high specificity of anti-PCNA can be retained if both the typical IFA AC-13 pattern and high titer anti-PCNA antibodies are detected by SPMAA [121]. The disadvantage of anti-PCNA is that it has low sensitivity $(<5 \%)$ for SLE and it may disappear after immunosuppression treatment [119].

Extracellular

\section{C1q}

Anti-C1q antibodies are predictive of and associated with LN, especially membranoproliferative disease $[122 \bullet, 123,124]$. In SLE with active LN, anti-C1q antibodies were found in up to $90 \%$ of patients $[124,125]$. The combined detection of C1q and dsDNA antibodies predicted flares of LN and have a combined sensitivity of $91 \%$ and specificity of $90 \%$ for LN [126]. Anti-C1q antibodies are as specific as high avidity dsDNA antibodies for LN and close a diagnostic and serological gap in some cases [122, 127].

\section{Phospholipids and related antigens [128]}

Autoantibodies directed to phospholipids (aCL, beta2 glycoprotein I ( $\beta 2$ GPI) and phospholipid-related targets (phosphatidyl serine/prothrombin complex or PS/PT) are a heterogeneous family of autoantibodies that are an important serological criteria in the classification of SLE $[79,80]$ and APS [128, 129]. Historically, anti-phospholipid antibodies (aPL) antibodies are traced to the identification of a biologically false-positive test for syphilis and the eventual link to cardiolipin, other anionic (negatively charged) phospholipids, and phospholipid binding proteins [2, 128]. Some studies indicate that they also have predictive value [130].

\section{Cardiolipin}

The importance of aCL antibodies in SLE and APS has had a rather tumultuous history. However, aCL remains a key classification criterion and has a prominent place in the laboratory diagnosis of both diseases. The primary use of the aCL assay is as an adjunct to anti-B2-GPI and lupus anticoagulant (LA) tests [128]. Its importance was underscored by a study reporting that $>25 \%$ of APS patients were negative for anti- $\beta 2$-GPI and LA but positive for aCL [131]. Hence, it remains an important assay to close the serological gap and classification of APS. IgG and IgM aCL test results should be reported as IgG anti-phospholipid units/mL (GPL)" and IgM anti-phospholipid units/mL (GPL)" units derived from calibrators composed of a pool of polyclonal aPLs. A positive aCL result is defined as a medium or high titer of greater than 40 GPL or MPL units. As an alternative, assay cutoffs established at greater than the 99th percentile of results obtained from a control group of at least 50 individuals is considered acceptable [79]. A significant limitation of the aCL test is its lack of specificity as it can be positive in other diseases, particularly those of infectious origin. 


\section{ß2-glycoprotein 1}

$\beta 2$-GPI consists of 326 amino acids and approximately $20 \%$ of the molecule is comprised of carbohydrates. $\beta 2$-GPI antibodies are reported to have a higher specificity but lower sensitivity for APS than aCL antibodies. High titer IgG- and IgM-isotype are diagnostic biomarkers and classification criteria of APS [128, 129] where they are associated with vascular thrombosis and recurrent spontaneous abortion. The value of anti- $\beta 2$-GPI antibodies has highest clinical value when they are detected on two or more occasions at least 12 weeks apart. The prevalence and levels of anti- $\beta 2$-GPI antibodies are significantly higher in SLE with arterial or venous thrombosis than in SLE patients without these complications and represent a significant risk factor for arterial thrombosis in SLE [132]. IgA anti-B2-GPI antibodies are reported to be more prevalent than IgG or IgM isotypes. The presence of both $\beta 2$-GPI and aCL antibodies is strongly associated with clinical symptoms of APS $[133,134]$. Unlike aCL antibodies, anti- $\beta 2-$ GPI antibodies are seldom detectable in infectious diseases. $\beta 2$-GPI is composed of five molecular domains, of which the exposed residues spanning the region from arginine (Arg) 39 to Arg43 of domain 1 (DI) represent the primary epitope bound by APS autoantibodies. The pathogenic subsets of anti- $\beta 2$-GPI associated with thrombosis are reported to also bind DI. An approach to increasing the specificity of anti- $\beta 2$-GPI testing was the development of a commercial immunoassay that included only DI of $\beta 2$-GPI [134-136]. Recent reports indicate the value of this assay in risk management [135] and predicting thrombosis and late pregnancy morbidity [137]. However, as a word of caution, there is variation of results in different commercially available assays [138].

\section{Non-criteria autoantibodies: phosphatidylserine/prothrombin complex}

Despite over 40 years of study and research, numerous difficulties are attributed to the APS criteria assays. In particular, no single or combination of APS criteria antibodies are present in up to $25 \%$ of patients who are strongly suspected of having APS, resulting in a "seronegative gap" $[128,139]$. A number of non-criteria autoantibodies, such as antiphosphatidylethanolamine, antibodies to proteins of the coagulation cascade, and antibodies to the PS/PT complex, have been associated with APS [128, 140,141]. Some interest has focused on the mitochondrial membrane antigen M5 which is associated with thrombocytopenia and fetal loss, and coexists with LA, aCL, anti- $\beta 2 \mathrm{GP} 1$, and biologically false-positive VDRL [142, 143]. With the availability of a commercial anti-PS/PT assay [144], a number of reports have focused on its value [145], particularly its use in closing the seronegative gap in APS [141, 146]. Although the presence of anti-PS/PT antibodies appear to be independent of the LA, they may be a potential substitute for the troubled LA assay $[146,147]$. The clinical utility of these assays, however, is limited by a paucity of prospective clinical data and lack of standardization [138]. Therefore, additional studies are required before any "noncriteria" immunoassays are included in standard APS classification criteria.

As noted above, more than 180 autoantibodies have been described in SLE and the list continues to grow. These "orphan" autoantibodies [81, 130] were not discussed here but the reader is referred to published studies of selected 


\section{Summary}

"orphan" autoantibodies [7, 148]. The reason that many of these antibodies are not commonly used is that they have yet to meet SMAARTT (specificitysensitivity, measurable, actionable, added value, realistic, titres, timely) criteria for development by laboratory diagnostics or met with demand from clinical practitioners [149•]. As SPMAAs become increasingly available, it is possible that some of these "orphan" biomarkers will find new uses in the prediction, diagnosis, and prognosis of SLE.

In summary, there is a need for evidence-based and unbiased approaches to ANA testing. In parallel, a compelling case can be made for attenuation of significant morbidity and health care expenditures in SLE by using ANA testing for "case finding" and making a much earlier diagnosis and prevention of high morbidity [150]. Given the shortcomings of ANA IFA testing [151], it appears that there should be a move to SPMAAs as the screening tests of choice for SLE.

\section{Compliance with Ethical Standards}

\section{Conflict of Interest}

Dr. Fritzler reports personal fees, non-financial support, and others from Inova Diagnostics Inc., others from Alexion Canada, personal fees from Werfen International, outside the submitted work. Dr. Choi declares that she has no conflict of interest.

\section{Human and Animal Rights and Informed Consent}

This article does not contain any studies with human or animal subjects performed by any of the authors.

Open Access This article is distributed under the terms of the Creative Commons Attribution 4.0 International License (http://creativecommons.org/licenses/by/4.0/), which permits unrestricted use, distribution, and reproduction in any medium, provided you give appropriate credit to the original author(s) and the source, provide a link to the Creative Commons license, and indicate if changes were made.

\section{References and Recommended Reading}

Papers of particular interest, published recently, have been highlighted as:

- Of importance

$\bullet \quad$ Of major importance

1. Hargraves MM, Richmond H, Morton R. Presentation of two bone marrow elements: the "tart" cells and the "L.E." cell. Mayo Clin Proc. 1948;23:25-8.

2. Benedek TC. History of Lupus. In: Wallace DJ, Hahn BH, editors. Dubois' lupus erythematosus and related conditions. Philadelphia: Elsevier; 2019. p. 1-14.

3. Mahler M, Meroni PL, Bossuyt X, Fritzler MJ. Current concepts and future directions for the assessment of autoantibodies to cellular antigens referred to as anti-nuclear antibodies. J Immunol Res. 2014;2014:315179.

4. Fritzler MJ. Widening spectrum and gaps in autoantibody testing for systemic autoimmune diseases. J Rheum Res. 2018; In press.

5. Sherer Y, Gorstein A, Fritzler MJ, Shoenfeld Y. Autoantibody explosion in systemic lupus erythematosus. Semin Arthritis Rheum. 2004;34:50137. 
6. Yaniv G, Twig G, Shor DB, Furer A, Sherer Y, Mozes O, et al. A volcanic explosion of autoantibodies in systemic lupus erythematosus: a diversity of 180 different antibodies found in SLE patients. Autoimmun Rev. 2014;14:75-9.

7. Fredi M, Cavazzana I, Quinzanini M, Taraborelli M, Cartella S, Tincani A, et al. Rare autoantibodies to cellular antigens in systemic lupus erythematosus. Lupus. 2014;23:672-7.

8. Choi MY, Clarke AE, St PY, Hanly JG, Urowitz MB, Romero-Diaz J, et al. Antinuclear antibody-negative systemic lupus erythematosus in an international inception cohort. Arthritis Care Res. 2018;

A recent evaluation of ANA negative SLE in a large inception SLE cohort for associations with autoantibodies, demographic and clinical features.

9. Fritzler MJ, Martinez-Prat L, Choi MY, Mahler M. The utilization of autoantibodies in approaches to precision health. Front Immunol. 2018;9:2682.

10. Fritzler MJ, Fritzler ML. Microbead-based technologies in diagnostic autoantibody detection. Expert Opin Med Diag. 2009;3:81-9.

11. Olsen NJ, Choi MY, Fritzler MJ. Emerging technologies in autoantibody testing for rheumatic diseases. Arthritis Res Ther. 2017;19:17.

Recent review of current ANA diagnostic technologies.

12. Meroni PL, Schur PH. ANA screening: an old test with new recommendations. Ann Rheum Dis. 2010;69:1420-2.

13. Hammonds T. Academic-Pharma drug discovery alliances: seeking ways to eliminate the valley of death. Future Med Chem. 2015;7:1891-9.

14. Aringer M, Dörner T, Leuchten N, Johnson S. Toward new criteria for systemic lupus erythematosus-a standpoint. Lupus. 2016;25(8):805-11.

15. Willems P, De LE, Westhovens R, Vanderschueren S, Blockmans D, Bossuyt X. Antinuclear antibody as entry criterion for classification of systemic lupus erythematosus: pitfalls and opportunities. Ann Rheum Dis. 2018.

16. Tedeschi SK, Johnson SR, Boumpas D, Daikh D, Dorner T, Jayne D, et al. Developing and refining new candidate criteria for SLE classification: an international collaboration. Arthritis Care Res. 2017;70:57181.

17. Colon-Franco JM, Bossuyt PMM, Algeciras-Schimnich A, Bird C, Engstrom-Melnyk J, Fleisher M, et al. Current and emerging multianalyte assays with algorithmic analyses-are laboratories ready for clinical adoption? Clin Chem. 2018;64:885-91.

18. Meroni PL, Chan EK, Damoiseaux J, Andrade LEC, Bossuyt X, Conrad K, et al. Unending story of the indirect immunofluorescence assay on HEp-2 cells: old problems and new solutions? Ann Rheum Dis. 2018.

19. Perez D, Gilburd B, Azoulay D, Shovman O, Bizzaro N, Shoenfeld Y. Antinuclear antibodies: is the indirect immunofluorescence still the gold standard or should be replaced by solid phase assays? Autoimmun Rev. 2018;17:548-52.
20. Bizzaro N, Brusca I, Previtali G, Alessio MG, Daves M, Platzgummer $\mathrm{S}$, et al. The association of solid-phase assays to immunofluorescence increases the diagnostic accuracy for ANA screening in patients with autoimmune rheumatic diseases. Autoimmun Rev. 2018; 17:541-7.

21.• Pisetsky DS. Antinuclear antibody testing - misunderstood or misbegotten? Nat Rev Rheumatol. 2017;13:495-50.

Review discusses important issues about the use of ANA testing in both the clinical and research settings.

22. Pisetsky DS, Lipsky PE. The Role of ANA Determinations in Classification Criteria for SLE. Arthritis Care Res. 2018.

23.• Jacobs JFM, Bossuyt X. Standardization and harmonization of autoimmune diagnostics. Clin Chem Lab Med. 2018;56:1563-7.

Review of the issues of harmonization/standardization of autoantibody testing including ANA.

24. Perez D, Gilburd B, Cabrera-Marante O, MartinezFlores JA, Serrano M, Naranjo L, et al. Predictive autoimmunity using autoantibodies: screening for antinuclear antibodies. Clin Chem Lab Med. 2018;56:1771-7.

25. Barr SG, Zonana-Nacach A, Magder LS, Petri M. Patterns of disease activity in systemic lupus erythematosus. Arthritis Rheum. 1999;42:2682-8.

26. Wiik AS. Anti-nuclear autoantibodies: clinical utility for diagnosis, prognosis, monitoring, and planning of treatment strategy in systemic immunoinflammatory diseases. Scand J Rheumatol. 2005;34:260-8.

27. Sjowall C, Bentow C, Aure MA, Mahler M. Twoparametric immunological score development for assessing renal involvement and disease activity in systemic lupus erythematosus. J Immunol Res. 2018;2018:1294680. https://doi.org/10.1155/2018/ 1294680eCollection;\%2018.:1294680.

28. Beastall GH, Brouwer N, Quiroga S, Myers GL. Traceability in laboratory medicine: a global driver for accurate results for patient care. Clin Chem Lab Med. 2017;55:1100-8.

29. Young IS. The enduring importance and challenge of commutability. Clin Chem. 2018;64:421-3.

30. Paxton A. New momentum in harmonizing lab results. CAP Today. 2018;32:1-34.

31. Agmon-Levin N, Damoiseaux J, Kallenberg C, Sack U, Witte T, Herold $M$, et al. International recommendations for the assessment of autoantibodies to cellular antigens referred to as anti-nuclear antibodies. Ann Rheum Dis. 2014;73:17-23.

32.• Damoiseaux J, von Muhlen CA, Garcia-de la Torre I, Carballo OG, de Melo CW, Francescantonio PL, et al. International consensus on ANA patterns (ICAP): the bumpy road towards a consensus on reporting ANA results. Auto Immun Highlights. 2016;7:1.

Describes the International Consensus on ANA Patterns (ICAP) initiative to establish a consensus on the nomenclature of the ANA IIF patterns on HEp-2 cells. 
33. Fritzler MJ, Wiik A, Fritzler ML, Barr SG. The use and abuse of commercial kits used to detect autoantibodies. Arthritis Res Ther. 2003;5:192-201.

34. Bossuyt X, Louche C, Wiik A. Standardisation in clinical laboratory medicine: an ethical reflection. Ann Rheum Dis. 2008;67:1061-3.

35. Van den Bremt S, Schouwers S, Van BM, Van HL. ANA IIF Automation: moving towards harmonization? Results of a multicenter study. J Immunol Res. 2017;2017:6038137.

36. Claessens J, Belmondo T, De LE, Westhovens R, Poesen $\mathrm{K}$, Hue S, et al. Solid phase assays versus automated indirect immunofluorescence for detection of antinuclear antibodies. Autoimmun Rev. 2018;17:533-40.

37. Kim J, Lee W, Kim GT, Kim HS, Ock S, Kim IS, et al. Diagnostic utility of automated indirect immunofluorescence compared to manual indirect immunofluorescence for anti-nuclear antibodies in patients with systemic rheumatic diseases: a systematic review and meta-analysis. Semin Arthritis Rheum. 2018; In press.

38. Bossuyt X, Hendrickx A, Frans J. Antinuclear antibody titer and antibodies to extractable nuclear antigens. Arthritis Rheum. 2005;53:987-8.

39. Oyaert M, Bossuyt X, Ravelingien I, Van HL. Added value of indirect immunofluorescence intensity of automated antinuclear antibody testing in a secondary hospital setting. Clin Chem Lab Med. 2016;54:e63-6.

40. Chan EK, Damoiseaux J, de Melo CW, Carballo OG, Conrad K, Francescantonio PL, et al. Report on the Second International Consensus on ANA Pattern (ICAP) workshop in Dresden 2015. Lupus. 2016;25:797-804.

41. Meroni PL, Borghi MO. Diagnostic laboratory tests for systemic autoimmune rheumatic diseases: unmet needs towards harmonization. Clin Chem Lab Med. 2018.

42. Bossuyt X, Fieuws S. Detection of antinuclear antibodies: added value of solid phase assay? Ann Rheum Dis. 2014;73:e10.

43. Jeong S, Hwang H, Roh J, Shim JE, Kim J, Kim GT, et al. Evaluation of an automated screening assay, compared to indirect immunofluorescence, an extractable nuclear antigen assay, and a line immunoassay in a large cohort of Asian patients with antinuclear antibodyassociated rheumatoid diseases: a multicenter retrospective study. J Immunol Res. 2018;2018:9094217.

44. Craft J, Hardin JA. Linked sets of antinuclear antibodies: what do they mean? J Rheumatol. 1987; 14(suppl):106-9.

45. Yang J, Xu Z, Sui M, Han J, Sun L, Jia X, et al. CoPositivity for Anti-dsDNA, -nucleosome and -histone antibodies in lupus nephritis is indicative of high serum levels and severe nephropathy. PLOS ONE. 2015;10:e0140441.

46. Menor AR, Jurado RA, Rodriguez Gutierrez FJ, Solis DR, Cardiel MH, Salaberri Maestrojuan JJ. Association of anti-Ro52, anti-Ro60 and anti-La antibodies with diagnostic, clinical and laboratory features in a referral hospital in Jerez. Reumatol Clin: Spain; 2015.
47.• Mummert E, Fritzler MJ, Sjowall C, Bentow C, Mahler $M$. The clinical utility of anti-double-stranded DNA antibodies and the challenges of their determination. J Immunol Methods. 2018;459:11-9.

Review summarizes the current knowledge about anti-dsDNA including its clinical associations and challenges in testing and interpretation of results.

48. Pisetsky DS. Anti-DNA antibodies - quintessential biomarkers of SLE. Nat Rev Rheumatol. 2016;12:10210 .

49. Yung S, Chan TM. Mechanisms of kidney injury in lupus nephritis - the role of anti-dsDNA antibodies. Front Immunol. 2015;6:475.

50. Andrejevic S, Jeremic I, Sefik-Bukilica M, Nikolic M, Stojimirovic B, Bonaci-Nikolic B. Immunoserological parameters in SLE: high-avidity anti-dsDNA detected by ELISA are the most closely associated with the disease activity. Clin Rheumatol. 2013;32:1619-26.

51. Gomez-Puerta JA, Burlingame RW, Cervera R. Antichromatin (anti-nucleosome) antibodies: diagnostic and clinical value. Autoimmun Rev. 2008;7:606-11.

52. Van Bavel CC, Dieker JW, Kroeze Y, Tamboer WP, Voll R, Muller S, et al. Apoptosis-induced histone H3 methylation is targeted by autoantibodies in systemic lupus erythematosus. Ann Rheum Dis. 2010;70:201-7.

53. Van Bavel CC, Dieker J, Muller S, Briand JP, Monestier $\mathrm{M}$, Berden JH, et al. Apoptosis-associated acetylation on histone $\mathrm{H} 2 \mathrm{~B}$ is an epitope for lupus autoantibodies. Mol Immunol. 2009;47:511-6.

54. Dwivedi N, Neeli I, Schall N, Wan H, Desiderio DM, Csernok E, et al. Deimination of linker histones links neutrophil extracellular trap release with autoantibodies in systemic autoimmunity. FASEB J. 2014;28:284051

55. Vaglio A, Grayson PC, Fenaroli P, Gianfreda D, Boccaletti V, Ghiggeri GM, et al. Drug-induced lupus: traditional and new concepts. Autoimmun Rev. 2018;17:912-8.

56. Fritzler MJ, Tan EM. Antibodies to histones in druginduced and idiopathic lupus erythematosus. J Clin Invest. 1978;62:560-7.

57. Mehra S, Fritzler MJ. The spectrum of anti-chromatin/ nucleosome autoantibodies: independent and interdependent biomarkers of disease. J Immunol Res. 2014;2014:368274.

58. Stinton LM, Barr SG, Tibbles LA, Yilmaz S, Sar A, Benedikttson $\mathrm{H}$, et al. Autoantibodies in lupus nephritis patients requiring renal transplantation. Lupus. 2007;16:394-400.

59. Abraham SJ, Rojas-Serrano J, Cabiedes J, Alcocer-Varela J. Antinucleosome antibodies may help predict development of systemic lupus erythematosus in patients with primary antiphospholipid syndrome. Lupus. 2004;13:177-81.

60. Cervera R, Vinas O, Ramos-Casals M, Font J, GarciaCarrasco M, Siso A, et al. Anti-chromatin antibodies in systemic lupus erythematosus: a useful marker for lupus nephropathy. Ann Rheum Dis. 2003;62:431-4. 
61. Kiss E, Lakos G, Szegedi G, Poor G, Szodoray P. Antinucleosome antibody, a reliable indicator for lupus nephritis. Autoimmunity. 2009;42:393-8.

62.• Rekvig OP, van d V, Seredkina N. Anti-nucleosome antibodies - a critical reflection on their specificities and diagnostic impact. Arthritis Rheum. 2014;65:1061-9.

An evidence-based critique of antinucleosome antibodies.

63. Schaper F, de LK, Horst G, Maas F, Bootsma H, Heeringa $P$, et al. Autoantibodies to Box A of high mobility group box-1 in systemic lupus erythematosus. Clin Exp Immunol. 2017;188:412-9.

64. Scaffidi P, Misteli T, Bianchi ME. Release of chromatin protein HMGB1 by necrotic cells triggers inflammation. Nature. 2002;418:191-5.

65. Magna M, Pisetsky DS. The role of cell death in the pathogenesis of SLE: is pyroptosis the missing link? Scand J Immunol. 2015;82:218-24.

66. Cully M. Connective tissue diseases: HMGB1 helps elicit anti-dsDNA antibody production in SLE. Nat Rev Rheumatol. 2013;9:321.

67. Abdulahad DA, Westra J, Bijzet J, Limburg PC, Kallenberg CG, Bijl M. High mobility group box 1 (HMGB1) and anti-HMGB1 antibodies and their relation to disease characteristics in systemic lupus erythematosus. Arthritis Res Ther. 2011;13:R71.

68. de SA, Westra J, Bijzet J, Limburg PC, Stegeman CA, Bijl $\mathrm{M}$, et al. Is serum HMGB1 a biomarker in ANCAassociated vasculitis? Arthritis Res Ther. 2013;15:R104.

69. Santoro P, De Andrea M, Migliaretti G, Trapani C, Landolfo S, Gariglio M. High prevalence of autoantibodies against the nuclear high mobility group (HMG) protein SSRP1 in sera from patients with SLE, but not other rheumatic diseases. J Rheumatol. 2002;29:90-3.

70.• Mahler M, Andrade LE, Casiano CA, Malyavantham K, Fritzler MJ. Anti-DFS70 antibodies: an update on our current understanding and their clinical usefulness. Expert Rev Clin Immunol. 2019;15:242-50.

Thorough review of the clinical relevance of anti-DFS autoantibodies.

71. Mahler M, Meroni PL, Andrade LE, Khamashta M, Bizzaro N, Casiano CA, et al. Towards a better understanding of the clinical association of anti-DFS70 autoantibodies. Autoimmun Rev. 2016;15:198-201.

72. Ganapathy V, Casiano CA. Autoimmunity to the nuclear autoantigen DFS70 (LEDGF): what exactly are the autoantibodies trying to tell us? Arthritis Rheum. 2004;50:684-8.

73. Ochs RL, Mahler M, Basu A, Rios-Colon L, Sanchez TW, Andrade LE, et al. The significance of autoantibodies to DFS70/LEDGFp75 in health and disease: integrating basic science with clinical understanding. Clin Exp Med. 2016;16:273-93.

74. Mariz HA, Sato EI, Barbosa SH, Rodrigues SH, Dellavance A, Andrade LE. Pattern on the antinuclear antibody-HEp-2 test is a critical parameter for discriminating antinuclear antibody-positive healthy individuals and patients with autoimmune rheumatic diseases. Arthritis Rheum. 2011;63:191-200.
75. Choi MY, Clarke AE, St PY, Hanly JG, Urowitz MB, Romero-Diaz J, et al. The prevalence and determinants of anti-DFS70 autoantibodies in an international inception cohort of systemic lupus erythematosus patients. Lupus. 2017;26:1051-9.

76. Albesa R, Sachs UJ, Infantino M, Manfredi M, Benucci $\mathrm{M}$, Baus $\mathrm{Y}$, et al. Increased prevalence of anti-DFS70 antibodies in young females: experience from large international multi-center study on blood donors. Clin Chem Lab Med. 2018.

77. Riemekasten G, Humrich JY, Hiepe F. Antibodies against the extractable nulcear antigens RNP, Sm, R0/ SSA, and La/SSB. In: Wallace DJ, Hahn BH, editors. Dubois' systemic lupus erythematosus and related syndromes. Philadelphia: Elsevier Inc; 2019. p. 36671.

78. Craft J. Antibodies to snRNPs in systemic lupus erythematosus. Rheum Dis Clin N Am. 1992;18:311-35.

79. Hochberg MC. Updating the American College of Rheumatology revised criteria for the classification of systemic lupus erythematosus. Arthritis Rheum. 1997;40:1725.

80. Petri M, Orbai AM, Alarcon GS, Gordon C, Merrill JT, Fortin PR, et al. Derivation and validation of systemic lupus international collaborating clinics classification criteria for systemic lupus erythematosus. Arthritis Rheum. 2012;64:2677-86.

81. Fritzler MJ. Challenges to the use of autoantibodies as predictors of disease onset, diagnosis and outcomes. Autoimmun Rev. 2008;7:616-20.

82. Sharp GC, Irvin W, Tan EM, Gould G, Holman HR. Mixed connective tissue disease - an apparently distinct rheumatic disease syndrome associated with a specific antibody to an extractable nuclear antigen (ENA). Am J Med. 1972;52:148-59.

83. Sakata K, Matsumoto Y, Satoh M, Oouchi A, Nagakura $\mathrm{H}$, Koito $\mathrm{K}$, et al. Clinical studies of immunohistochemical staining of DNA-dependent protein kinase in oropharyngeal and hypopharyngeal carcinomas. Radiat Med. 2001;19:93-7.

84. Belizna C, Henrion D, Beucher A, Lavigne C, Ghaali A, Levesque $\mathrm{H}$. Anti-Ku antibodies: clinical, genetic and diagnostic insights. Autoimmun Rev. 2010;9:691-4.

85. Mimori T, Akizuki M, Yamagata H, Inada S, Yoshida S, Homma M. Characterization of a high molecular weight acidic nuclear protein recognized by autoantibodies in sera from patients with polymyositisscleroderma overlap. J Clin Invest. 1981;68:611-20. Reeves WH. Use of monoclonal antibodies for the characterization of novel DNA-binding proteins recognized by human autoimmune sera. J Exp Med. 1985; 161:18-39.

87. Wang J, Satoh M, Kabir F, Shaw M, Domingo MA, Mansoor R, et al. Increased prevalence of autoantibodies to ku antigen in African American versus white patients with systemic lupus erythematosus. Arthritis Rheum. 2001;44:2367-70.

88. Hoa S, Hudson M, Troyanov Y, Proudman S, Walker J, Stevens W, et al. Single-specificity anti-Ku antibodies in 
an international cohort of 2140 systemic sclerosis subjects: clinical associations. Medicine (Baltimore). 2016;95:e4713.

89. Vitali C, Bombardieri S, Jonsson R, Moutsopoulos HM, Alexander EL, Carsons SE, et al. Classification criteria for Sjogren's syndrome: a revised version of the European criteria proposed by the American-European Consensus Group. Ann Rheum Dis. 2002;61:554-8.

90. Routsias JG, Tzioufas AG. Autoimmune response and target autoantigens in Sjogren's syndrome. Eur J Clin Investig. 2010;40:1026-36.

91. Izmirly PM, Halushka MK, Rosenberg AZ, Whelton S, Rais-Bahrami K, Nath DS, et al. Clinical and pathologic implications of extending the spectrum of maternal autoantibodies reactive with ribonucleoproteins associated with cutaneous and now cardiac neonatal lupus from SSA/Ro and SSB/La to U1RNP. Autoimmun Rev. 2017;16:980-3.

92. Arbuckle MR, McClain MT, Rubertone MV, Scofield $\mathrm{RH}$, Dennis GJ, James JA, et al. Development of autoantibodies before the clinical onset of systemic lupus erythematosus. N Engl J Med. 2003;349:1526-33.

93. Grela P, Sawa-Makarska J, Gordiyenko Y, Robinson CV, Grankowski N, Tchorzewski M. Structural properties of the human acidic ribosomal $\mathrm{P}$ proteins forming the P1-P2 heterocomplex. J Biochem. 2008;143:16977.

94. Lin A, Wittmann-Liebold B, McNally J, Wool IG. The primary structure of the acidic phosphoprotein $\mathrm{P} 2$ from rat liver $60 \mathrm{~S}$ ribosomal subunits. Comparison with ribosomal 'A' proteins from other species. J Biol Chem. 1982;257:9189-97.

95. Francoeur AM, Peebles CL, Heckman KJ, Lee JC, Tan EM. Identification of ribosomal protein autoantigens. J Immunol. 1985;135:2478-384.

96. Pasoto SG, Viana VS, Bonfa E. The clinical utility of anti-ribosomal $P$ autoantibodies in systemic lupus erythematosus. Expert Rev Clin Immunol. 2014; 10:1493-503

97. Toubi E, Shoenfeld Y. Clinical and biological aspects of anti-P-ribosomal protein autoantibodies. Autoimmun Rev. 2007;6:119-25.

98. Mahler M, Agmon-Levin N, van LM, Shoenfeld Y, Waka A, Hiepe F, et al. Multi-center evaluation of autoantibodies to the major ribosomal P C22 epitope. Rheumatol Int. 2012;32:691-8.

99. Zandman-Goddard G, Shoenfeld Y. Antiribsomal P Antibodies. In: Shoenfeld Y, Meroni PL, Gershwin ME, editors. Autoantibodies. Amsterdam: Elsevier BV; 2014. p. 225-31.

100. Karassa FB, Afeltra A, Ambrozic A, Chang DM, De KF Doria A, et al. Accuracy of anti-ribosomal P protein antibody testing for the diagnosis of neuropsychiatric systemic lupus erythematosus: an international metaanalysis. Arthritis Rheum. 2006;54:312-24.

101. Hanly JG, Urowitz MB, Siannis F, Farewell V, Gordon $\mathrm{C}$, Bae SC, et al. Autoantibodies and neuropsychiatric events at the time of systemic lupus erythematosus diagnosis: results from an international inception cohort study. Arthritis Rheum. 2008;58:843-53.

102. Mahler M, Kessenbrock K, Raats J, Williams RC Jr, Fritzler MJ. Characterization of the human autoimmune response to the major C-terminal epitope of the ribosomal P proteins. J Mol Med. 2003;81:194-204.

103. Lin JL, Dubljevic V, Fritzler MJ, Toh BH. Major immunoreactive domains of human ribosomal $\mathrm{P}$ proteins lie $\mathrm{N}$-terminal to a homologous $\mathrm{C}-22$ sequence: application to a novel ELISA for systemic lupus erythematosus. Clin Exp Immunol. 2005;141:15564.

104. Mahler M, Kessenbrock K, Raats J, Fritzler MJ. Technical and clinical evaluation of anti-ribosomal P protein immunoassays. J Clin Lab Anal. 2004;18:21523.

105. Mahler M, Ngo J, Schulte-Pelkum J, Luettich T, Fritzler MJ. Limited reliability of the indirect immunofluorescence technique for the detection of anti-Rib-P antibodies. Arthritis Res Ther. 2008;10:R131.

106. Reichlin M. Serological correlations with nephritis in systemic lupus erythematosus. Clin Immunol. 2005;117:12-4.

107. Gerli R, Caponi L. Anti-ribosomal P protein antibodies. Autoimmun. 2005;38:85-92.

108. Fritzler MJ, Hanson C, Miller J, Eystathioy T. Specificity of autoantibodies to SS-A/Ro on a transfected and overexpressed human $60 \mathrm{kDa}$ Ro autoantigen substrate. J Clin Lab Anal. 2002;16:103-8.

109. Malik S, Bruner GR, Williams-Weese C, Feo L, Scofield $\mathrm{RH}$, Reichlin $\mathrm{M}$, et al. Presence of anti-La autoantibody is associated with a lower risk of nephritis and seizures in lupus patients. Lupus. 2007;16:863-6.

110. Yoshimi R, Ishigatsubo Y, Ozato K. Autoantigen TRIM21/Ro52 as a possible target for treatment of systemic lupus erythematosus. Int J Rheumatol. 2012;2012:718237.

111. Bolland S, Garcia-Sastre A. Vicious circle: systemic autoreactivity in Ro52/TRIM21-deficient mice. J Exp Med. 2009;206:1647-51.

112. Kyriakidis NC, Kapsogeorgou EK, Gourzi VC, Konsta OD, Baltatzis GE, Tzioufas AG. Toll-like receptor 3 stimulation promotes Ro52/TRIM21 synthesis and nuclear redistribution in salivary gland epithelial cells, partially via type I interferon pathway. Clin Exp Immunol. 2014;178:548-60.

113. Schulte-Pelkum J, Fritzler M, Mahler M. Latest update on the Ro/SS-A autoantibody system. Autoimmun Rev. 2009;8:632-7.

114. Dugar M, Cox S, Limaye V, Gordon TP, RobertsThomson PJ. Diagnostic utility of anti-Ro52 detection in systemic autoimmunity. Postgrad Med J. 2010;86:79-82.

115. Hudson M, Pope J, Mahler M, Tatibouet S, Steele R, Baron $\mathrm{M}$, et al. Clinical significance of antibodies to Ro52/TRIM21 in systemic sclerosis. Arthritis Res Ther. 2012;14:R50.

116. Retamozo S, Akasbi M, Brito-Zeron P, Bosch X, Bove A, Perez-De-Lis M, et al. Anti-Ro52 antibody testing 
influences the classification and clinical characterisation of primary Sjogren's syndrome. Clin Exp Rheumatol. 2012;30:686-92.

117. Lu R, Robertson JM, Bruner BF, Guthridge JM, Neas BR, Nath SK, et al. Multiple autoantibodies display association with lymphopenia, proteinuria, and cellular casts in a large, ethnically diverse SLE patient cohort. Autoimmune Dis. 2012;2012:819634.

118. Murng SHK, Thomas M. Clinical associations of the positive anti Ro52 without Ro60 autoantibodies: undifferentiated connective tissue diseases. J Clin Pathol 2017;71:12-9.

119. Mahler M, Miyachi K, Peebles C, Fritzler MJ. The clinical significance of autoantibodies to the proliferating cell nuclear antigen (PCNA). Autoimmun Rev. 2012;11:771-5.

120. Vermeersch P, De Beeck KO, Lauwerys BR, Van den Bergh K, Develter M, Marien G, et al. Antinuclear antibodies directed against proliferating cell nuclear antigen are not specifically associated with systemic lupus erythematosus. Ann Rheum Dis. 2009;68:1791-3.

121. Mahler M, Silverman ED, Fritzler M. Novel diagnostic and clinical aspects of anti-PCNA antibodies detected by novel detection methods. Lupus. 2010;19:152733.

122.• Beurskens FJ, van Schaarenburg RA, Trouw LA. C1q, antibodies and anti-C1q autoantibodies. Mol Immunol. 2015;68:6-13.

Excellent review of anti-C1q antibodies.

123. Trouw LA, Daha MR. Role of anti-C1q autoantibodies in the pathogenesis of lupus nephritis. Expert Opin Biol Ther. 2005;5:243-51.

124. de Leeuw K, Kallenberg CGM. Antibodies against C1q antibodies. In: Wallace DJ, Hahn BH, editors. Dubois' lupus erythematosus and related syndromes. Philadelphia: Elsevier Inc.; 2019. p. 372-3.

125. Vitre B, Gudimchuk N, Borda R, Kim Y, Heuser JE, Cleveland DW, et al. Kinetochore-microtubule attachment throughout mitosis potentiated by the elongated stalk of the kinetochore kinesin CENP-E. Mol Biol Cell. 2014;25:2272-81.

126. Matrat A, Veysseyre-Balter C, Trolliet P, Villar E, Dijoud F, Bienvenu J, et al. Simultaneous detection of anti-C1q and anti-double stranded DNA autoantibodies in lupus nephritis: predictive value for renal flares. Lupus. 2011;20:28-34.

127. Eggleton P, Ukoumunne OC, Cottrell I, Khan A, Maqsood S, Thornes J, et al. Autoantibodies against $\mathrm{C} 1 \mathrm{q}$ as a diagnostic measure of lupus nephritis: systematic review and meta-analysis. J Clin Cell Immunol. 2014;5:210.

128. Giles I, Cohen H, Ioannou Y. Pathogenesis of antiphospholipid antibody syndrome. In: Wallace DJ, Hahn BH, editors. Dubois' lupus erythematosus and related syndromes. Philadelphia: Elsevier Inc.; 2019. p. 324-37.

129. Miyakis S, Lockshin MD, Atsumi T, Branch DW, Brey $\mathrm{RL}$, Cervera R, et al. International consensus statement on an update of the classification criteria for definite antiphospholipid syndrome (APS). J Thromb Haemost. 2006;4:295-306.

130. Meroni PL, Shoenfeld Y. Predictive, protective, orphan autoantibodies: the example of the antiphospholipid antibodies. Autoimmun Rev. 2008;7:585-7.

131. Nash MJ, Camilleri RS, Kunka S, Mackie IJ, Machin SJ, Cohen $\mathrm{H}$. The anticardiolipin assay is required for sensitive screening for antiphospholipid antibodies. J Thromb Haemost. 2004;2:1077-81.

132. Nojima J, Kuratsune H, Suehisa E, Futsukaichi Y, Yamanishi H, Machii T, et al. Association between the prevalence of antibodies to $\beta_{2}$-glycoprotein I, prothrombin, protein $\mathrm{C}$, protein $\mathrm{S}$, and annexin $\mathrm{V}$ in patients with systemic lupus erythematosus and thrombotic and thrombocytopenic complications. Clin Chem. 2001;47:1008-15.

133. Obermoser G, Bitterlich W, Kunz F, Sepp NT. Clinical significance of anticardiolipin and anti-beta2glycoprotein I antibodies. Int Arch Allergy Immunol. 2004;135:148-53.

134. Andreoli L, Chighizola CB, Nalli C, Gerosa M, Borghi $\mathrm{MO}$, Pregnolato F, et al. Clinical characterization of antiphospholipid syndrome by detection of IgG antibodies against beta2 -glycoprotein i domain 1 and domain 4/5: ratio of anti-domain 1 to antidomain $4 / 5$ as a useful new biomarker for antiphospholipid syndrome. Arthritis Rheum. 2015;67:2196204.

135. Mahler M, Norman GL, Meroni PL, Khamashta M. Autoantibodies to domain 1 of beta 2 glycoprotein 1 : a promising candidate biomarker for risk management in antiphospholipid syndrome. Autoimmun Rev. 2012;12:313-7.

136. Cousins L, Pericleous C, Khamashta M, Bertolaccini ML, Ioannou Y, Giles I, et al. Antibodies to domain I of beta-2-glycoprotein I and IgA antiphospholipid antibodies in patients with 'seronegative' antiphospholipid syndrome. Ann Rheum Dis. 2015;74:317-9.

137. Chighizola CB, Pregnolato F, Andreoli L, Bodio C, Cesana L, Comerio C, et al. Beyond thrombosis: antibeta2GPI domain 1 antibodies identify late pregnancy morbidity in anti-phospholipid syndrome. J Autoimmun. 2018;90:76-83.

138. Chayoua W, Kelchtermans H, Moore GW, Musial J, Wahl D, de LB, et al. Identification of high thrombotic risk triple-positive antiphospholipid syndrome patients is dependent on anti-cardiolipin and antibeta2glycoprotein I antibody detection assays. J Thromb Haemost. 2018;16:2016-23.

139. Zohoury N, Bertolaccini ML, Rodriguez-Garcia JL, Shums Z, Ateka-Barrutia O, Sorice M, et al. Closing the serological gap in the antiphospholipid syndrome: the value of "Non-criteria" antiphospholipid antibodies. J Rheumatol. 2017;44:1597-602.

140. Sciascia S, Khamashta MA, Bertolaccini ML. New tests to detect antiphospholipid antibodies: antiprothrombin (aPT) and anti-phosphatidylserine/ 
prothrombin (aPS/PT) antibodies. Curr Rheumatol Rep. 2014;16:415.

141. Zhang S, Wu Z, Zhang W, Zhao J, Norman GL, Zeng X, et al. Antibodies to phosphatidylserine/prothrombin (aPS/PT) enhanced the diagnostic performance in Chinese patients with antiphospholipid syndrome. Clin Chem Lab Med. 2018;56:939-46.

142. La Rosa L, Covini G, Galperin C, Catelli L, Del Papa N, Reina $\mathrm{G}$, et al. Anti-mitochondrial M5 type antibody represents one of the serological markers for antiphospholipid syndrome distinct from anticardiolipin and anti-beta2-glycoprotein I antibodies. Clin Exp Immunol. 1998;112:144-51.

143. Meroni PL, Harris EN, Brucato A, Tincani A, Barcellini W, Vismara A, et al. Anti-mitochondrial type M5 and anti-cardiolipin antibodies in autoimmune disorders: studies on their association and cross-reactivity. Clin Exp Immunol. 1987;67:484-91.

144. Sciascia S, Sanna G, Murru V, Khamashta MA, Bertolaccini ML. Validation of a commercially available kit to detect anti-phosphatidylserine/prothrombin antibodies in a cohort of systemic lupus erythematosus patients. Thromb Res. 2014;133:451-4.

145. Amengual O, Forastiero R, Sugiura-Ogasawara M, Otomo K, Oku K, Favas C, et al. Evaluation of phosphatidylserine-dependent antiprothrombin antibody testing for the diagnosis of antiphospholipid syndrome: results of an international multicentre study. Lupus. 2017;26:266-76.

146. Shi H, Zheng H, Yin YF, Hu QY, Teng JL, Sun Y, et al. Antiphosphatidylserine/prothrombin antibodies (aPS/PT) as potential diagnostic markers and risk predictors of venous thrombosis and obstetric complications in antiphospholipid syndrome. Clin Chem Lab Med. 2018;56:614-24.

147. Bertolaccini ML, Sciascia S, Murru V, GarciaFernandez C, Sanna G, Khamashta MA. Prevalence of antibodies to prothrombin in solid phase (aPT) and to phosphatidylserine-prothrombin complex (aPS/ PT) in patients with and without lupus anticoagulant. Thromb Haemost. 2013;109:207-13.

148. Stinton LM, Eystathioy T, Selak S, Chan EKL, Fritzler MJ. Autoantibodies to protein transport and messenger RNA processing pathways: endosomes, lysosomes, Golgi complex, proteasomes, assemblyosomes, exosomes and GW Bodies. Clin Immunol. 2004;110:30-44.

149. Fritzler MJ, Mahler M. Redefining systemic lupus erythematosus - SMAARTT proteomics. Nat Rev Rheumatol. 2018;14:451-.

Brief overview of emerging newer technolgies and approaches to replace the ANA test.

150. Choi MY, Barber MR, Barber CE, Clarke AE, Fritzler MJ. Preventing the development of SLE: identifying risk factors and proposing pathways for clinical care. Lupus. 2016;25:838-49.

151. Fritzler MJ. The antinuclear antibody (ANA) test: Last or lasting gas $\backslash \mathrm{p}$ ? Arthritis Rheum. 2011;63:19-22.

\section{Publisher's Note}

Springer Nature remains neutral with regard to jurisdictional claims in published maps and institutional affiliations. 